\title{
Guided autobiography as method for retirement preparation program
}

\begin{abstract}
Retirement preparation programs (RPPs) have been used in Brazil since the 1980s to help those who will retire from their formal jobs. However, studies on this topic are rare. This study discusses for the first time the applicability of guided autobiography, a method of life history writing, in RPPs. Guided autobiography (GAB) was developed in 1970 by the gerontologist James Birren, and this method is broadly used in interventions with old people, based on discussion of branched and coherent topics with their life cycle. The method briefly described here and its operationalization are innovative approaches to be implemented in RRPs.
\end{abstract}

Keywords: retirement, autobiography, program
Volume 2 Issue I - 2017

\author{
Lucia Helena de Freitas Pinho França,' Silvia \\ Miranda Amorim² \\ 'Professor of Graduate Studies in Psychology, Universidade \\ Salgado de Oliveira, Brazil \\ ${ }^{2}$ Graduate Studies in Psychology,Universidade Salgado de \\ Oliveira, Brazil
}

\author{
Correspondence: Lucia Helena de Freitas Pinho França, \\ Universidade Salgado de Oliveira, Rua Marechal Deodoro, Rio \\ de Janeiro, Brazil,Tel +55(2I) 98877 I774,
} Email lucia.franca@gmail.com

Received: May 20, 2017 | Published: August 23, 2017
Abreviations: RRP, retirement preparation program; GAB, guided autobiography

\section{Introduction}

In Brazil, retirement preparation programs (RRPs) were developed in the 1980s and are designed to help participant have new experiences, develop skills, and discover new interests and to reflect on their life project. ${ }^{1}$ Recent studies in this area are primarily theoretical ${ }^{2}$ and the use of methods and approaches in such a way that consider participants' reality and experience is becoming important.

Guided autobiography (GAB) is a method of life history writing created 40 years ago by James Birren, a pioneer researcher in gerontology. ${ }^{3}$ The institutions with which Birren was affiliated, such as the Ethel Percy Andrus Gerontology Center of University of Southern California (USC) and the Center on Aging of University of California, Los Angeles (UCLA), became known for promoting researches on aging, cognitive changes and autobiographic studies.

In Birren's view, personal interpretations on life (not related to age) influence well-being and changes of each individual throughout life. ${ }^{4}$ The phrase "If you do not know where to go, at least know where you have been" illustrates Birren's point of view and his interest in developing a method to enable individuals to explore their past. ${ }^{6}$ Birren developed the GAB over many years, and he achieved success in his approaches, but he has never tried as a retirement planning project. The first author of this paper had the opportunity to participate in one of visiting group to Dr. Birren at UCLA in 2002; there she obtained his support for using GAB in RRPs.

\section{Case presentation}

GAB was planned to combine group and individual experiences, such as i) group interaction and leadership, ii) particular reflections on life regarding specific topics, and iii) shared thinking in a encouraging group. ${ }^{7}$ Groups must be developed with 10 to 16 individuals; there are at least 10 meetings, each 2 hours long.

The use of GAB in RRPs must be through initial sessions in which the facilitator explains the objective of the study, which is to help participants to reconstruct a life project for retirement. This project seeks to analyze branched points for each participant and resources accumulated during that person's lifetime. Sessions comprise a branched topic of life, such as family, job and career, friendship, leisure and cultural activities, role of the money, body and self-image likes and dislikes, spirituality, goals, and meaning of life. In the first GAB session, the objective of the study is explained, as are the branched points and the process of the study. Next, participants select the most important topics for the meetings for the next seven sessions. The last two sessions are designated to prepare the life project, assess it, and discuss the follow-up process with the group

Each session ends with a short assessment from the facilitator about the subject addressed that day and an announcement of the next meeting topic; this enables the participant to bring a personal written report on the topic, one to two pages long. ${ }^{8}$ GAB helps participants to explore such issues as who we are and who we are becoming, experiences and proposals that shape the present, and pathways and possibilities for the future. At the end of each session, feedback given by the group must be supportive, encouraging, and positive. ${ }^{9}$

The GAB method enables participants to achieve personal and specific group goals by the use of collaborative meetings in an informative and pre-determined manner. This approach is different from that used traditional RRPs in Brazil. The method applies to individuals in the pre-retirement phase in the format proposed by Birren. His proposals encourage the search for new approaches and help people to understand how they deal with themselves. They also provide the opportunity to restructure relationships in an adequate manner for themselves and society. When using this method, the facilitator must discuss the main risk and protective factors for wellbeing in retirement and should also seek to contribute with reflections on a personal and professional life project to be done over the short, medium, and long term.

\section{Discussion}

Retirement planning entails analysis of a number of aspects of life for each individual who is close to this decision, and it must consider survival and well-being in the present and future. In this 
analysis, emotional, family, financial, health, and leisure resources gain importance. The GAB provides an opportunity to improve understanding and acceptance of oneself and elaborate a project that can be tackled in the future. ${ }^{7}$ The use of GAB is indicated among older adults, particularly those who willing to change their lifestyle or those who are facing a decisive stage in their life, such as retirement.

As emphasized by França ${ }^{10}$ those who are close to retirement must obtain the resources needed to manage their own life project, handle losses, and reinforce gains related to this time in relation to their wishes and possibilities. The sharing of life histories with others from a group of people in the same situation stimulates memories from the past, which sometimes are neglected; it also enable individuals to re-experience parts of their lives inside others' histories. As a result, participants learn how to enjoy their unique experiences and similarities with others, as well as learn more about themselves in a friendly environment. ${ }^{7}$ For this reason, GAB should be considered a method to construct an adequate project of life for RRP. ${ }^{11}$ Further studies should be done to prove the efficacy of the GAB method in the pre-retirement population.

\section{Acknowledgements}

We thank to FAPERJ the- Foundation for Research Support of Rio de Janeiro - FAPERJ (first author) and The Brazilian Coordination of Higher Education and Personnel Improvement -CAPES (second author) for the funding and support given for retirement studies in Brazil.

\section{Conflict of interest}

All authors declare they have no conflicts of interest to report.

\section{References}

1. França LH. Programas de Preparação para Aposentadoria: Diagnóstico, estratégias para implantação [Retirement Preparation Programs: Diagnosis and implementation strategies]. In: H Mendonça, MC Ferreira, editors. Análise e Diagnóstico Organizacional: Teoria e prática. 2016. p. 319-347.
2. França LHF, Amorim SM, Siqueira BAR, et al. Perfil dos Programas de Preparação para a Aposentadoria em empresas públicas e privadas brasileiras [Retirement Preparation Program Profile in Brazilian Public and Private Companies]. Revista de Estudos Interdisciplinares sobre o Envelhecimento, Brazil.

3. American Society on Aging. In Memory of James (Jim) E Birren. USA; 2016.

4. Birren J. How do I think I got there? The LLI Review, Brazil; 2006.

5. Birren JE, Birren BA. Autobiography: Exploring the self and encouraging development. In: JE Birren, GM Kenyon J, editors. Aging and biography: Explorations in adult development. 1996. p. 283-299.

6. Birren JE, Svensson CM. Guided Autobiography: Writing and Telling the Stories of Lives. The LLI Review, 2014. p. 113-119.

7. Birren JE, Deutchman ED. Guiding autobiography groups for older adults: Exploring the fabric of life. Baltimore: The Johns Hopkins University Press. USA; 1991.

8. Svensson CM, Bernell BL. Guided Autobiography: Stimulate Your Brain, Enhance Well-Being, Develop Community, and Create a Legacy. The California Psychologist. 2013;46(6):15-18.

9. Thornton J. The Guided Autobiography Experience Method: A Learning Experience. Int J Aging Hum Dev. 2008;66(2):155-173.

10. França LHP. Social predictors influencing the attitudes of top executives towards retirement: a cross-cultural study. Revista de Administração Contemporânea. 2009;13(1):17-35.

11. França, LHFP, Soares DP. Retirement preparation as part of lifelong learning. Psicologia: Ciência e Profissão. 2009;29(4):738-750. 